Pacific Economic Paper No. 287

JANUARY 1999

\title{
International Trade and Environmental Policy: How Effective is 'Eco-Dumping'?
}

Xinpeng $\mathrm{Xu}$

Australian National University 
This work is copyright. Apart from those uses which may be permitted under the Copyright Act 1968 as amended, no part may be reproduced by any process without written permission.

Pacific Economic Papers are published under the direction of the Research Committee of the Australia-Japan Research Centre. Current members are:

Prof. Stuart Harris (Chair) The Australian National University

Prof. Sandra Buckley Griffith University

Prof. Ken Davis

The University of Melbourne

Prof. Peter Drysdale The Australian National University

Prof. Ron Duncan The Australian National University
Assoc. Prof. Christopher Findlay The University of Adelaide

Prof. Jim Fox The Australian National University

Prof. Ross Garnaut The Australian National University

Prof. Keith Hancock Australian Industrial Relations Commission

Prof. Jocelyn Horne Macquarie University
Prof. John Nevile The University of New South Wales

Prof. WarwickMcKibbin The Australian National University

Prof. Alan Rix

The University of Queensland

Mr Ben Smith The Australian National University

Papers submitted for publication are subject to double-blind external review by two referees.

The Australia-Japan Research Centre is part of the Asia Pacific School of Economics and Management, The Australian National University, Canberra.

ISSN 07288409

ISBN 0864132344

Australia-Japan Research Centre

Asia Pacific School of Economics and Management

The Australian National University

Canberra ACT 0200

Telephone: (61 2) 62493780

Facsimile: (61 2) 62490767

Email: ajrcgen@ajrc.anu.edu.au

URL: http://ajrcnet.anu.edu.au 


\section{CONTENTS}

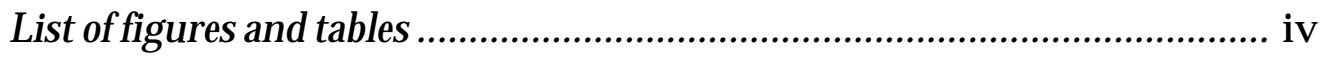

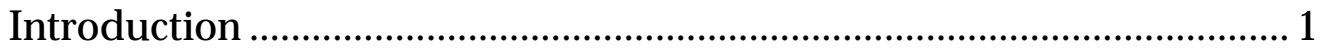

Technology, increasing returns to scale and the generalised GNP function ................................................................. 3

Approximation of the generalised GNP function

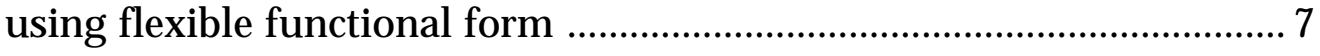

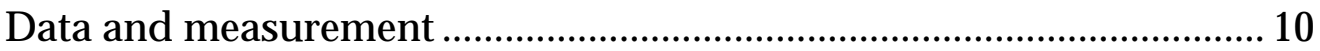

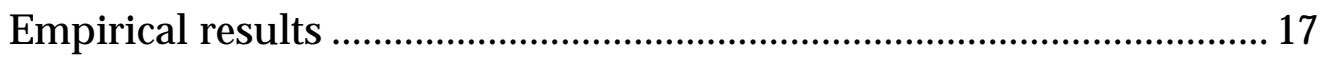

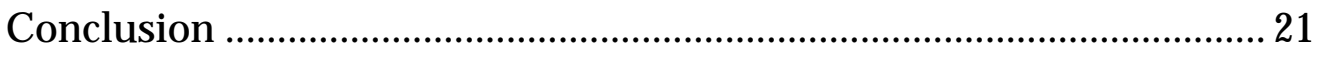

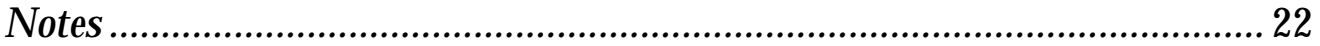

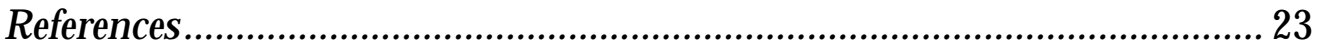




\section{FIGURES}

Figure 1 Geometric illustration of maximisation of GNP function

Figure 2 Geometric illustration of maximisation of GNP function

\section{TABLES}

Table 1 Industry classification codes for environmentally sensitive industries

Table 2 Environmental stringency and GDP per capita for selected countries

Table 3 The Spearman correlation test 14

Table 4 Share of manufacturing in GDP and shares of selected industries in total manufacturing in 1988.

Table 5 Summary statistics of the sectoral share for each industry across 30 countries

Table 6 Environmental stringency rank measured by GDP per capita

Table $7 \quad$ SURE estimates of the GDP share equations .......................... 18

Table 8 Definition of the variables ..................................................... 20

Table 9 Estimates of GDP share equation: standardised coefficients

Table 10 SURE estimates of GDP share equation: a normalisation of standardised coefficients 


\title{
International Trade and Evnvironmental Policy: How EFFEctive is 'Eco-Dumping'?
}

\begin{abstract}
The effects of environmental regulations on the international competitiveness of domestic industries have become an increasing concern in the trade liberalisation process in the 1990s. This paper examines the significance of environmental policy for trade. A generalised GNP function, which incorporates both technology changes and increasing returns to scale is set up and a flexible translog function form is used to approximate this generalised GNP function. Seemingly unrelated regression is employed to estimate a system of sectoral share equations derived from the generalised GNP function. The basic hypothesis is that while the environmental factor is not a significant determinant of the international competitiveness of environmentally sensitive industries, technology is. The result supports this hypothesis and suggests that socalled eco-dumping is not an effective strategy in this context.
\end{abstract}

\section{Introduction}

A country is regarded as engaging in 'ecological-dumping,, ${ }^{1}$ or 'eco-dumping', when it gains international competitiveness in environmentally sensitive industries ${ }^{2}$ by imposing relatively lax environmental standards on the production of a good. More precisely, 'eco-dumping' can be defined as a policy which 'prices environmentally harmful activities at less than the marginal cost of environmental degradations, i.e. a policy which does not internalise all environmental externalities' (Rauscher 1994: 824).

'Eco-dumping' and its counterpart, anti-dumping, have emerged as a new issue threatening the trade liberalisation agenda of the Asia Pacific Economic Cooperation forum (APEC) and the World Trade Organisation (WTO). As the trade and environment debate intensified, there has been a resurgence of calls for a 'level playing field', 'harmonisation of environmental standards' or 'fair trade', and fears of loss of international competitiveness of environmentally sensitive industries from developed countries in the 1990s. Developing countries, on the other hand, see these calls as new protectionism, in the form of hidden nontariff barriers, and are concerned about market access problems (Dua and Esty 1997).

An even more important issue facing developing countries concerns appropriate development strategies. Is there a conflict between environmental standards and international 


\section{Pacific Economic Papers}

competitiveness? Do developing countries need to sacrifice their hopes for economic development, or international competitiveness more narrowly, in the interests of higher environmental standards? ${ }^{3}$ Any degradation of environment due to lax environmental standards will have negative effects on the sustainability of economic development. The question then becomes clear. Is there a choice to be made between economic development (or narrowly, international competitiveness of ESG industries) versus environmental standards or should economic development take the environmental standards into account?

There have been several normative analyses of this issue in the literature. These include Bhagwati and Hudec 1996, Chichilnisky 1994, Brander and Taylor 1997, Anderson and Blackhurst 1992, Esty 1994, Dua and Esty 1997, Porter and van der Linde 1995, Markusen 1997 and Barrett 1994, among others. What is lacking is further empirical analysis, as pointed out in a 1995 ministerial report to the OECD Council, 'the next stage of the OECD's work programme should include empirical analysis of selected policy areas and economic sectors' (OECD 1995).

In the context of this literature, this paper examines trade liberalisation and environmental policy from an empirical perspective. It aims to investigate the effectiveness of 'ecodumping', if any, on the international competitiveness of environmentally sensitive industries. I seek to examine whether the introduction of stringent environmental policies will lead to a decline in ESG industries in the presence of a technology factor. To this end, a generalised GNP function, which incorporates both technological change and increasing returns to scale, is set up and a flexible translog function form is used to approximate this generalised GNP function. Seemingly unrelated regression (SUR) techniques are used to estimate a system of sectoral share equations derived from the generalised GNP function. Environmental stringency is treated as a factor of production, as discussed extensively in Xu (1999a), together with capital, labour, land, mineral, oil and coal endowments. The technology level is regarded as an important determinant of the sectoral share in production. The basic hypothesis is that the environmental factor is not a significant determinant of the international competitiveness of environmentally sensitive industries, while technology is.

The rest of this paper proceeds as follows. The generalised GNP function is derived in the next section. A flexible translog function form is set up to approximate the generalised GNP function in section 3. Section 4 discusses data and measurement issues. Section 5 reports the econometric results and tests their robustness. The final section presents a conclusion. 
No. 287 January 1999

\section{Technology, increasing returns to scale and the generalised GNP function}

Following Samuelson (1953), Dixit and Norman (1980), Woodland (1982), Kohli (1993) and Harrigan (1997), I consider a small open economy characterised by fixed aggregate factor supplies, constant returns to scale, and competitive market clearing. It can be shown that the equilibrium for the production sector can be obtained using the following maximisation problem $^{4}$

Max $\mathbf{p} \cdot \mathbf{y}$ subject to $\mathbf{y} \in \mathbf{Y}(\mathbf{v})$

$$
\mathbf{p}, \mathbf{y} \in 3^{\mathrm{N}}, \mathbf{v} \in 3^{\mathrm{M}},
$$

where $\mathbf{y}$ is the $\mathrm{N}$-dimensional output vector, $\mathbf{p}$ is the price vector for output, $\mathbf{v}$ is the $\mathrm{M}$ dimensional factor endowment vector, and $\mathbf{Y}(\mathbf{v})$ is the set of all output vectors which can be produced given the technology and the factor endowment. Its boundary is called the production possibility frontier. This is essentially the problem that a central planner would attempt to solve given the price vector $\mathbf{p}$ and the factor endowment vector $\mathbf{v}$. The optimum $\mathbf{y}$ is clearly a function of $\mathbf{p}$ and $\mathbf{v}: \mathbf{y}^{*}=\mathbf{f}(\mathbf{p}, \mathbf{v})$. Substituting this optimum output vector $\mathbf{y}^{*}$ into the objective function $\mathbf{p} \cdot \mathbf{y}$ gives the GNP function which is a function of $\mathbf{p}$ and $\mathbf{v}$ as well. The GNP function can be written as

$$
\mathrm{G}=\mathrm{G}(\mathbf{p}, \mathbf{v})
$$

$\mathrm{G}$ (p, v) is non-decreasing, linearly homogenous, and concave in $\mathbf{v}$, and non-decreasing, linearly homogenous, and convex in $\mathbf{p}$.

This optimisation problem may also be illustrated diagrammatically in Figure 1 for the case of $2 \times 2$. In Figure 1, the area OAB is the production possibility set given the economy's factor endowment. The optimum output vector $\mathbf{y}^{0}$ can be solved given the price vector, $\mathbf{p}$. This gives the point $\mathrm{y}^{0}$ where the highest iso-GNP line is tangent to the production possibility curve given the factor endowment vector $\mathbf{v}$. The price vector $\mathbf{p}$, drawn starting from any point $\mathrm{y}^{1}$ (not 
shown on the graph) on the iso-GNP line, must be orthogonal to any vector starting at ${ }^{1}$ and lying on the iso-GNP line. This is so because for any $\mathrm{y}^{2}$ that itself lies on iso-GNP line, we have

$\mathbf{p} \mathbf{y}^{1}=\mathbf{p} \mathbf{y}^{2}=$ GNP.

Hence

$\mathbf{p} \Delta \mathbf{y}=0$ for $\Delta \mathbf{y}=\mathbf{y}^{2}-\mathbf{y}^{1}$.

Thus, vector $\mathbf{p}$ is orthogonal to vector $\Delta \mathbf{y}$. Note that when we draw the price vector in the diagram, we use the 'units' on the axes to represent units of prices rather than goods.

\section{Figure 1 Geometric illustration of maximisation of GNP function}

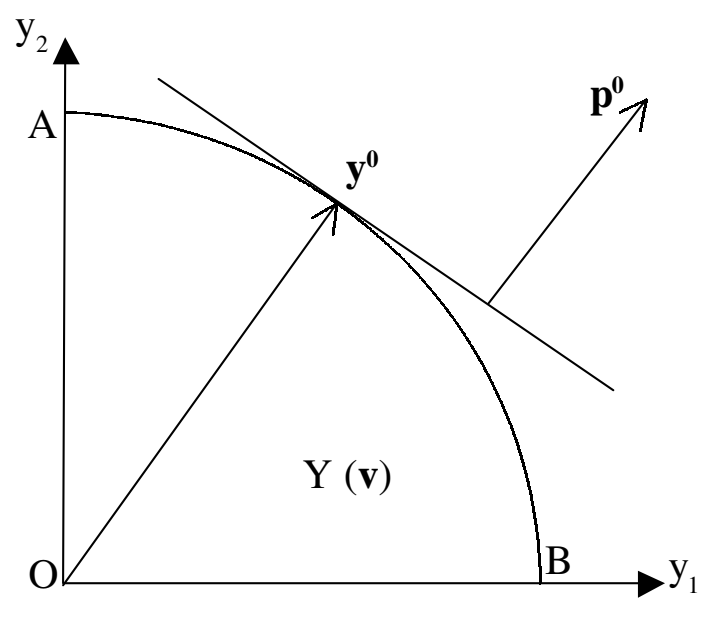

The GNP function approach has proved very useful in international trade theory analysis and trade empirical studies. As long as the GNP function is twice continuously differentiable, applying Hotelling's lemma gives the gradients (derivative) of $G(\mathbf{p}, \mathbf{v})$ with respect to $\mathbf{p}$ and $\mathbf{v}$ which are the vector of output supplies and vector of factor price, respectively. 


$$
\mathbf{y}=\mathrm{G}_{\mathbf{p}}(\mathbf{p}, \mathbf{v}) \text { and } \mathbf{w}=\mathrm{G}_{\mathbf{v}}(\mathbf{p}, \mathbf{v})
$$

Constant returns to scale and no technological change are two of the basic assumptions underling the Heckscher-Ohlin theorem. It has been argued by 'new trade theory' that increasing returns to scale is one important factor that explains trade patterns, especially the large observed volume of intra-industry trade. We can demonstrate that the assumption of constant returns to scale can easily be relaxed in the generalised GNP function framework.

In the case of increasing returns to scale, a firm's output is not only a function of factorial value added $f(\mathbf{v})$, as in the case of constant returns to scale, but also a function of industry output $\mathrm{g}(\mathrm{Y})$.

$$
\mathbf{y}=g(Y) f(\mathbf{v})
$$

where g' $>0$ and g" $<0$, indicating that the larger the industry, the more efficient the firm will be. And $\mathbf{Y}=\sum \mathbf{y}=g(\mathbf{Y}) f(\mathbf{v})$ is the industry output vector. Let the equilibrium industry output vector be $\underline{\mathrm{Y}}$, then the firm will maximise $\{\mathbf{p g}(\underline{\mathrm{Y}})\} \times \mathrm{f}(\mathbf{v})$, where $\mathrm{g}(\underline{\mathrm{Y}})$ can be treated as a scalar of price vector $\mathbf{p}$. The GNP function then becomes

$$
\mathrm{G}=\mathrm{G}(\mathbf{p g}(\underline{\mathbf{Y}}), \mathbf{v})
$$

or

$$
\mathrm{G}=\mathrm{G}(\theta \mathbf{p}, \mathbf{v})
$$

where $\theta=\operatorname{diag}\left(\theta_{1}, \theta_{2}, \ldots, \theta_{\mathrm{N}}\right)=\mathrm{g}(\underline{\mathbf{Y}})$.

Similarly, applying Hotelling's lemma gives the gradients (derivative) of $\mathrm{G}(\mathbf{p g}(\underline{\mathbf{Y}})$, v) with respect to $\mathbf{p}$ and $\mathbf{v}$, which are the vector of output supplies and vector of factor price, respectively. 


$$
\partial \mathrm{G}(\theta \mathbf{p}, \mathbf{v}) / \partial \mathbf{p}=\{\partial \mathrm{G}(\theta \mathbf{p}, \mathbf{v}) / \partial(\theta \mathbf{p})\} \bullet\{\partial(\theta \mathbf{p}) / \partial \mathbf{p}\}=\theta \mathrm{f}(\mathbf{v})=\mathbf{y}
$$

and

$$
\partial \mathrm{G}(\theta \mathbf{p}, \mathbf{v}) / \partial \mathbf{v}=\mathbf{w}
$$

where $\partial \mathrm{G}(\theta \mathbf{p}, \mathbf{v}) / \partial(\theta \mathbf{p})=\mathrm{f}(\mathbf{v})$ and $\partial(\theta \mathbf{p}) / \partial \mathrm{p}=\mathrm{g}(\underline{\mathbf{Y}})$. This can be illustrated diagrammatically as in Figure 2. Comparing Figure 2 with Figure 1, we can see that increasing returns to scale can be modelled as industry-specific price changes, and the optimum output vector is again given by the gradient of the GNP function.

Figure 2 Geometric illustration of maximisation of GNP function

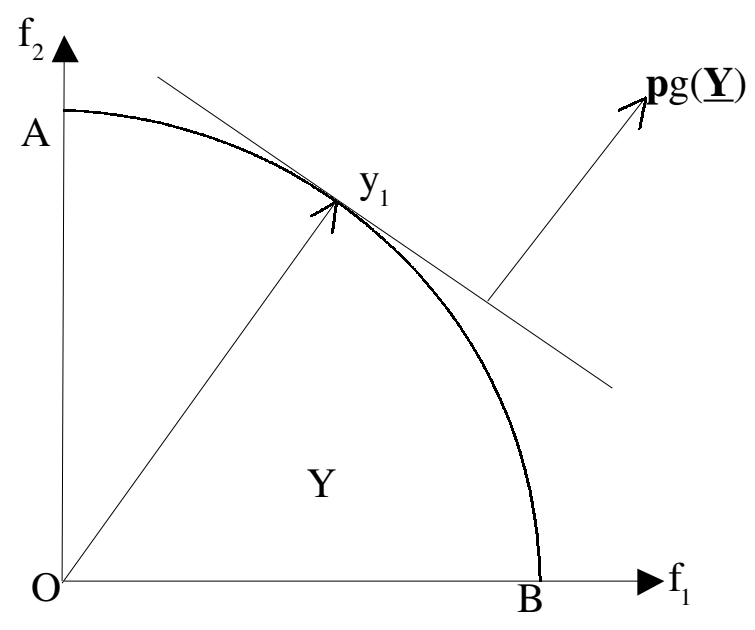

Dixit and Norman (1980) and Harrigan (1997) arrived at a similar result by relaxing the assumption of no technology difference across countries and industries. Suppose there exists a production function for each good given by

$$
\mathbf{y}=\varphi f(\mathbf{v})
$$


where $\mathrm{j}$ is a scalar parameter relative to some base country. The assumption of the existence of distinct production functions implies that joint production is ruled out. The resulting GNP function can be shown to have the form

$$
\mathrm{G}=\mathrm{G}(\varphi \mathbf{p}, \mathbf{v})
$$

where $\varphi=\operatorname{diag}\left\{\varphi_{1}, \varphi_{2}, \ldots, \varphi_{\mathrm{N}}\right\}$. This formulation implies that industry-specific neutral technology change can be modelled in the same way as an industry-specific price increase, as in the case of increasing returns to scale.

However, it is now clear that the parameter attached to the price vector stands not only for the effect of industry-specific neutral technology change, as discussed by Harrigan (1997), but also for increasing returns to scale, which was not included in Harrigan's study.

\section{Approximation of the generalised GNP function using flexible functional form}

Having laid out the theoretical background, the next step towards testing the hypothesis is to approximate the GNP function using a flexible functional form. Since its introduction by Christensen, Jorgenson and Lau in 1973, the translog function has received considerable attention in the empirical literature. It has several advantages over the Cobb-Douglas and CES functions. Following Woodland (1982), Kohli (1978; 1991 and 1993) and Harrigan (1997), a translog function is used to approximate the GNP function. The translog GNP function takes the form

$$
\begin{array}{rl}
\ln \mathrm{G}(\theta \mathbf{p}, \mathbf{v})=\ln \alpha_{00} & +\sum \alpha_{0 j} \ln \theta_{\mathrm{j}} \mathrm{p}_{\mathrm{j}}+\sum \beta_{0 i} \ln \mathrm{v}_{i} \\
& +1 / 2 \sum \sum \alpha_{j k} \ln \theta_{j} \mathrm{p}_{j} \ln \theta_{k} \mathrm{p}_{k} \\
j k & k \\
& +1 / 2 \sum \sum \beta_{i m} \ln v_{i} \ln \mathrm{v}_{m}+\sum \sum \gamma_{j i} \ln \theta_{j} \mathrm{p}_{j} \ln \mathrm{v}_{i} \\
i m & j
\end{array}
$$




\section{Pacific Economic Papers}

where $j$ and $k$ stand for products that are in $3^{\mathrm{N}}$ while $i$ and $m$ denote factor supplies that are in $3^{\mathrm{M}}, \theta$ is a variable capturing the effects of both technology level and increasing returns to scale. We can impose symmetry by requiring that $\alpha_{j k}=\alpha_{k j}$ and $\beta_{i m}=\beta_{m i}$ for all $j, k, i$ and $m$. Since the GNP function is linear in $\mathbf{v}$ and $\mathbf{p}$, we require

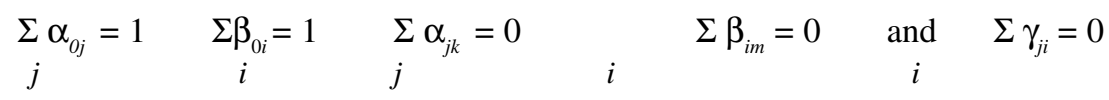

Differentiating $\ln \mathrm{G}(\theta \mathbf{p}, \mathbf{v})$ with respect to each $\ln \mathrm{p}_{j}$ and imposing the homogeneity restrictions $\Sigma_{j} \alpha_{j k}=0$ and $\Sigma_{i} \gamma_{j i}=0$ and adjusting the terms gives the sectoral share in GNP, $\mathrm{S}_{j}=\mathrm{p}_{j} \mathrm{y}_{j} / \mathrm{G}$ as a function of technology parameters, prices and factor supplies:

$$
\begin{array}{r}
\mathrm{S}_{j}=\alpha_{0 j}+\sum_{k=2}^{\mathrm{N}} \alpha_{k j} \ln \left(\mathrm{p}_{k} / \mathrm{p}_{1}\right)+\underset{k=2}{\mathrm{~N}} \alpha_{k j} \ln \left(\theta_{k} / \theta_{1}\right)+\sum_{i=2}^{\sum} \gamma_{i j} \ln \left(\mathrm{v}_{i} / \mathrm{v}_{1}\right) \\
j=1,2, \ldots,(\mathrm{N}-1)
\end{array}
$$

In the case of free trade, each country faces the same prices but they differ in their factor endowments, technology level and scale economy. This implies $\Sigma_{\mathrm{k}} \alpha_{k j} \ln \left(\mathrm{p}_{k} / \mathrm{p}_{1}\right)$ is a constant and it can be factored into the constant term. Following Harrigan (1997), if one takes into account the fact that many goods are non-traded, only tradable goods price will be absorbed into the constant term. The problem is that data for non-tradable goods prices are generally not available. One approach is to treat them as random with some estimable probability distribution that may generate a stochastic process with a constant dummy for each country and a classic disturbance term. These reformulations are defined by $\alpha$ in (11). Therefore, we have the following estimated equation

$$
\begin{array}{r}
\mathrm{S}_{j}=\alpha+\sum_{k=1}^{\mathrm{N}} \alpha_{k j} \ln \left(\theta_{\mathrm{k}}\right)+\sum_{i=2}^{\mathrm{M}} \gamma_{i j} \ln \left(\mathrm{v}_{i} / \mathrm{v}_{1}\right)+\varepsilon_{j} \\
\quad j=1,2, \ldots,(\mathrm{N}-1)
\end{array}
$$


The only sign restriction on this equation in theory is that the own-technology/returns to scale effect, $\alpha_{j j}$, is positive: holding other factors constant, an increase in the technology level should lead to an increase in its sectoral share. Theory also requires that the cross-technology effects are symmetric, $\alpha_{k j}=\alpha_{j k}$ for all sectors $j$ and $k, k^{1} j$.

Since $\theta$ is a variable capturing the effects of both technology level and increasing returns to scale, we assume the following relationship between the effect of technology level $\theta_{t}$, and increasing returns to scale $\theta_{\mathrm{s}}$

$$
\theta=\theta_{\mathrm{t}} \tau \theta_{\mathrm{s}}^{1-\tau}
$$

Substituting equation (12) into (11) gives

$$
\begin{array}{r}
\mathrm{S}_{j}=\alpha+\sum_{k=1}^{\mathrm{N}} \alpha_{k j} \tau \ln \left(\theta_{\mathrm{kt}}\right)+\sum_{k=1}^{\mathrm{N}} \alpha_{k j}(1-\tau) \ln \left(\theta_{\mathrm{ks}}\right)+\sum_{i=2}^{\mathrm{M}} \gamma_{i j} \ln \left(\mathrm{v}_{i} / \mathrm{v}_{1}\right)+\varepsilon_{j} \\
j=1,2, \ldots,(\mathrm{N}-1)
\end{array}
$$

With data on technology level, increasing returns to scale and factor endowments, equation (13) can be estimated by substituting equation (12). However, data on increasing returns to scale across industries and/or countries are generally not available. The best way to approach this problem may be to treat the increasing returns to scale effect as random with some estimable probability distribution as $\zeta$

$$
\zeta_{\mathrm{i}}=\rho_{\mathrm{i}}+\mathrm{e}_{\mathrm{i}}
$$

where $\mathrm{e}_{\mathrm{i}}$ is white noise. Rewriting equation (13) using (14) gives the equation to be estimated

$$
\begin{array}{r}
\mathrm{S}_{j}=\beta+\sum_{k=1}^{\mathrm{N}} \beta_{k j} \ln \left(\theta_{k t}\right)+\sum_{i=2}^{\mathrm{M}} \gamma_{i j} \ln \left(\mathrm{v}_{i} / \mathrm{v}_{1}\right)+\mathrm{e}_{\mathrm{i}} \\
\quad j=1,2, \ldots,(\mathrm{N}-1)
\end{array}
$$




\section{Pacific Economic Papers}

where constant term $\beta$, which equals to $\left(\alpha+\sum \alpha_{k j}(1-\mathrm{t}) \ln \left(\theta_{\mathrm{ks}}\right)\right)$ with $k=1$ to $\mathrm{N}$, combines the effects of all goods prices, non-traded goods technology parameters and increasing returns to scale effect and $\beta_{k j}=\alpha_{k j}$ t.

\section{Data and measurement}

To estimate the above model, I need data on sectoral output share, technology level and factor endowment. As to sectoral output share, I choose ISIC 33, 34, 35, 36 and 37, as follows. These five industries are generally regarded to be the environmentally sensitive industries. All data are for 1988.

\section{Sectoral output share}

Data on sectoral output value added and sectoral employment are available from the UNIDO (United Nations Industrial Development Organisation) industrial statistics database. GDP in current price data are from the World Bank CD-ROM World Development Indicators 1997. Sectoral output value added is divided by GDP to obtain the sectoral output share as the dependent variable.

Table 1 Industry classification codes for environmentally sensitive industries

ISIC code Descriptions
1. 33
Manufacture of wood and wood products
2. 34
Manufacture of paper, paper products and printing
3. 35
Manufacture of chemicals and chemical products
4. 36
Manufacture of non-metal mineral products
5. 37
Manufacture of basic metal products

Source: UNIDO(1992). 
No. 287 January 1999

\section{Technology}

Technology is a variable that has no uniform definition, especially in the empirical literature. Total factor productivity is sometimes used to measure Hicks-neutral technology differences across industries (and/or countries). Since data for sectoral factor supplies are not available, sectoral value added per worker is therefore used instead. This can be justified as follows. The first is the fact that embodied technology changes (especially labour augmenting changes) can be regarded as a reasonable approximation of the process of technology progress. As shown in Barro and Sala-i-Martin (1995: 34), the long-term experience of the United States and some developed countries 'suggests that a useful theory would predict that per capita growth rates approach constants in the long run; that is, the model would possess a steady state'. Therefore technological progress must take the Harrod-neutral (labour augmenting) form in order for the model to have a steady state. Second, if the production function takes the Cobb-Douglas form, it is possible for technological progress to be both Hicks-neutral and Harrod-neutral. Suppose the production function, in the case of two factors, Capital $K_{t}$ and Labour $L_{t}$, is

$$
\mathrm{Y}_{t}=\mathrm{f}\left(\mathrm{K}_{t}, \mathrm{~A}(t) \mathrm{L}_{t}\right)=\beta \mathrm{K}_{t} \alpha\left(\mathrm{A}(t) \mathrm{L}_{t}\right)^{1-} \alpha
$$

After arranging items on the right-hand side, this function becomes

$$
\mathrm{Y}_{t}=(\mathrm{A}(t))^{1-} \alpha \beta \mathrm{K}_{t} \alpha \mathrm{L}_{t}^{1-} \alpha=\gamma \mathrm{K}_{t} \alpha \mathrm{L}_{t}^{1-} \alpha
$$

This function satisfies the criteria of both Hicks-neutrality and Harrod-neutrality.

\section{Environmental factor}

Data on the environmental factors is generally not available. In light of this, an aggregate index number is often chosen. For example, quoting data from Walter and Ugelow (1979), Tobey (1990) chose an index number to approximate a country's environmental stringency which is measured on a scale from one to seven for a set of 23 countries. 


\section{Pacific Economic Papers}

The latest attempt to 'measure the status of environmental policy and performance' is a World Bank project by Dasgupta et al. (1995). This dataset is shown in Table 2. Since sectoral output value added and factor endowment data are not available for some of the countries included and therefore there is a lack of degrees of freedom in the econometric study, this dataset is not explicitly employed. However, I construct the environmental stringency variable on the basis of their data.

Table 2 shows the environmental stringency index developed by the World Bank project. One interesting feature of this dataset is that the relationship between per capita income and environmental stringency is positive and highly significant. As can be seen in Table 3, the Spearman correlation coefficients between the environmental stringency index, and ICPGDP and PCGNP is -0.86987 and -0.8553 , respectively. Both are statistically significant at the 0.01 per cent level. This suggests that higher income countries tend to have more stringent environmental policies. Based on this result I use GDP per capita as an instrumental variable' to the environmental stringency index. Of course, the higher a country's GDP per capita, the more stringent its environmental policy.

\section{Other factor endowments}

Although data on sectoral factor supplies are difficult to get for the countries of interest, national factor endowment data are used to measure the fixed effect of factor abundance. The national factor endowment can be interpreted as the mean of the sectoral factor input. The justification can easily be found in the literature on the production possibility frontier where provincial data is used as the mean of firm level data. Since the econometrically estimated model is a system equation, these factor endowment variables examine whether countries with higher endowments in one factor will tend to be associated with a higher sectoral share in one of the sectors. These factor endowments are provided by Song (1996) and include: (1) Capital: capital stock at constant prices assuming 15-year average life of assets, in US\$ million; (2) Labour force; (3) Labour 1: number of workers classified as professional or technical; (4) Labour 2: number of literate non-professional workers; (5) Labour 3: number of illiterate workers; (6) Land; (7) Oil: crude oil production plus production of natural gas, in thousands of US dollars; (8) Coal: production of primary solid fuels (coal, lignite, and brown coal) plus natural gas, in thousands of US dollars; (9) Minerals: composite of 12 kinds of major minerals. Note that the sum of Labour 1 to 3 is equal to the total labour force in each sector of each country. 
No. 287 January 1999

Table 2 Environmental stringency and GDP per capita for selected countries

\begin{tabular}{|c|c|c|c|c|}
\hline Country & $\begin{array}{l}\text { Environment } \\
\text { Index }\end{array}$ & ICPGDP & PCGNP & $\begin{array}{c}\text { Rank by } \\
\text { Environment } \\
\text { Index }\end{array}$ \\
\hline Germany & 951 & 16920 & 22320 & 1 \\
\hline Switzerland & 945 & 21690 & 32680 & 2 \\
\hline Netherlands & 900 & 14600 & 17320 & 3 \\
\hline Finland & 894 & 15620 & 26040 & 4 \\
\hline Ireland & 871 & 9130 & 9550 & 5 \\
\hline Bulgaria & 737 & 7900 & 2250 & 6 \\
\hline Korea & 686 & 7190 & 5400 & 7 \\
\hline Jamaica & 633 & 3030 & 1500 & 8 \\
\hline Czech & 622 & 3470 & 3470 & 9 \\
\hline S.Africa & 619 & 5500 & 2530 & 10 \\
\hline Tunisia & 589 & 3979 & 1440 & 11 \\
\hline Trinidad & 563 & 8510 & 3610 & 12 \\
\hline China & 530 & 1950 & 370 & 13 \\
\hline India & 507 & 1150 & 350 & 14 \\
\hline Pakistan & 506 & 1770 & 380 & 15 \\
\hline Brazil & 492 & 4780 & 2680 & 16 \\
\hline Jordan & 474 & 4530 & 1240 & 17 \\
\hline Ghana & 465 & 1720 & 390 & 18 \\
\hline Kenya & 464 & 1120 & 370 & 19 \\
\hline Thailand & 448 & 4610 & 1420 & 20 \\
\hline Philippines & 447 & 2320 & 730 & 21 \\
\hline Paraguay & 443 & 3120 & 1110 & 22 \\
\hline Egypt & 441 & 3100 & 600 & 23 \\
\hline Malawi & 441 & 670 & 200 & 24 \\
\hline Zambia & 437 & 810 & 420 & 25 \\
\hline Nigeria & 396 & 1420 & 290 & 26 \\
\hline Mozambique & 368 & 620 & 80 & 27 \\
\hline Bangladesh & 363 & 1050 & 210 & 28 \\
\hline Tanzania & 341 & 540 & 110 & 29 \\
\hline Papua NG & 329 & 1500 & 860 & 30 \\
\hline Bhutan & 256 & 510 & 190 & 31 \\
\hline Ethiopia & 253 & 310 & 120 & 32 \\
\hline
\end{tabular}

Note: $\quad$ PCGNP stands for per capita GNP and ICPGDP for per capita GDP estimates compiled by the UN International Comparisons Program. 'Environment Index' denotes the environmental stringency index compiled by Dasgupta et al., World Bank.

Source: Dasgupta et al. (1995). 
Table 3 The Spearman correlation test

\begin{tabular}{lccc}
\hline & Rank & ICPGDP & PCGNP \\
\hline ICPGDP & 0.8678 & & \\
& $(0.0001)$ & & \\
PCGNP & 0.8537 & 0.9554 & \\
& $(0.0001)$ & $(0.0001)$ & \\
Environmental stringency & -0.9999 & -0.8699 & -0.8553 \\
& $(0.0001)$ & $(0.0001)$ & $(0.0001)$ \\
\hline
\end{tabular}

Note: $\quad$ Numbers in parentheses are p-values. See also Table 2 for notations of variables.

Source: Author's calculations.

\section{Data summary}

The country coverage in this dataset includes 16 out of the 18 APEC countries and most OECD countries. Table 4 gives a summary of how the 30 countries differ in their production. Each column gives the percentage share of manufacturing value added in total GDP. The last column gives the percentage share of the five environmentally sensitive industries' value added in total manufacturing value added. One of the interesting features is that environmentally sensitive industries account for 40 to 50 per cent of the total manufacturing value added for the majority of the countries. Other columns give the percentage share of each industry's value added in total manufacturing value added. We can see that countries vary largely as to the composition of their environmentally sensitive industries' production. The variability in these environmentally sensitive industries' output share across countries is the focus of the study in next section. 
No. 287 January 1999

Table 4 Share of manufacturing in GDP and shares of selected industries in total manufacturing in 1988

\begin{tabular}{|c|c|c|c|c|c|c|c|}
\hline & Manufacturing & $\begin{array}{c}\text { Wood } \\
\text { Products }\end{array}$ & $\begin{array}{l}\text { Paper \& } \\
\text { Printing }\end{array}$ & Chemicals & $\begin{array}{l}\text { Non- } \\
\text { Metal }\end{array}$ & Metal & ESGs \\
\hline Australia & 15.4 & 5.7 & 11.2 & 13.4 & 4.8 & 9.8 & 44.8 \\
\hline Canada & 21.5 & 6.2 & 15.2 & 15.7 & 3.4 & 7.8 & 48.2 \\
\hline Chile & 18.1 & 3.5 & 9.2 & 17.1 & 3.2 & 26.5 & 59.4 \\
\hline China & 35.7 & 1.3 & 3.4 & 19.5 & 7.0 & 9.6 & 40.8 \\
\hline Denmark & 20.7 & 4.7 & 10.0 & 15.4 & 5.2 & 1.5 & 36.8 \\
\hline Finland & 28.9 & 7.0 & 24.3 & 10.6 & 4.5 & 5.2 & 51.7 \\
\hline France & 21.7 & 3.0 & 7.4 & 19.6 & 4.3 & 5.6 & 39.9 \\
\hline Germany & 32.1 & 2.5 & 4.2 & 20.9 & 3.5 & 5.4 & 36.6 \\
\hline Greece & 25.8 & 2.3 & 5.3 & 16.8 & 8.0 & 8.1 & 40.6 \\
\hline Hong Kong & 20.5 & 1.0 & 7.7 & 9.7 & 0.7 & 0.6 & 19.7 \\
\hline India & 17.8 & 0.5 & 3.2 & 24.0 & 4.4 & 13.9 & 46.0 \\
\hline Indonesia & 19.7 & 13.9 & 4.7 & 16.4 & 3.9 & 8.3 & 47.2 \\
\hline Italy & 23.5 & 3.0 & 6.5 & 14.0 & 6.1 & 7.7 & 37.4 \\
\hline Japan & 28.2 & 2.7 & 7.9 & 15.7 & 4.6 & 7.1 & 37.9 \\
\hline Korea, Rep. & 32.1 & 1.5 & 4.5 & 17.5 & 4.3 & 7.2 & 35.1 \\
\hline Malaysia & 21.2 & 6.9 & 4.2 & 26.5 & 6.1 & 3.4 & 47.1 \\
\hline Mexico & 26.8 & 0.5 & 4.4 & 23.0 & 7.7 & 11.8 & 47.3 \\
\hline Netherlands & 18.8 & 1.8 & 10.1 & 25.9 & 3.7 & 5.3 & 46.7 \\
\hline New Zealand & 18.2 & 6.6 & 14.1 & 13.9 & 3.8 & 3.8 & 42.2 \\
\hline Norway & 14.0 & 6.1 & 14.6 & 11.8 & 3.6 & 12.9 & 48.9 \\
\hline Philippines & 25.6 & 3.9 & 4.0 & 22.8 & 3.8 & 6.2 & 40.7 \\
\hline Portugal & 27.9 & 4.3 & 11.5 & 15.6 & 9.0 & 3.1 & 43.3 \\
\hline Singapore & 29.9 & 1.4 & 5.4 & 20.7 & 1.2 & 1.2 & 30.0 \\
\hline Spain & 24.1 & 4.0 & 7.1 & 17.9 & 6.7 & 6.4 & 42.1 \\
\hline Sri Lanka & 15.4 & 1.2 & 4.1 & 9.9 & 6.1 & 0.9 & 22.0 \\
\hline Sweden & 25.2 & 6.1 & 16.3 & 12.9 & 2.9 & 6.1 & 44.3 \\
\hline Taiwan & 37.2 & 3.0 & 4.1 & 24.0 & 3.8 & 6.6 & 41.4 \\
\hline Thailand & 25.8 & 2.8 & 18.2 & 17.0 & 6.3 & 2.6 & 46.9 \\
\hline Britain & 25.2 & 3.3 & 10.7 & 17.7 & 5.4 & 5.0 & 42.0 \\
\hline United States & 20.0 & 3.0 & 11.2 & 17.0 & 2.9 & 4.2 & 38.3 \\
\hline
\end{tabular}

Notes: The column labelled 'Manufacturing' gives the percentage share of manufacturing value added in total GDP. The column labelled 'ESGs' gives the percentage share of the five environmentally sensitive industries' value added in total manufacturing value added. Other columns give the percentage share of each industry's value added in total manufacturing value added.

Source: Author's calculations. 
Table 5 Summary statistics of the sectoral share for each industry across 30 countries

\begin{tabular}{lccccc}
\hline & Wood Prod. & $\begin{array}{c}\text { Paper \& } \\
\text { Printing }\end{array}$ & Chemicals & Non-Metal & Metal \\
\hline Mean & 0.0074 & 0.0183 & 0.0373 & 0.0094 & 0.0142 \\
Standard Deviation & 0.0040 & 0.0116 & 0.0197 & 0.0045 & 0.0135 \\
Sample Variance & 0.0000 & 0.0001 & 0.0004 & 0.0000 & 0.0002 \\
Minimum & 0.0004 & 0.0025 & 0.0110 & 0.0014 & 0.0010 \\
Maximum & 0.0153 & 0.0532 & 0.0879 & 0.0228 & 0.0743 \\
\hline
\end{tabular}

Note: $\quad$ Sectoral share refers to share of GDP (not in percentage terms).

Source: Author's calculations.

Table 6 Environmental stringency rank measured by GDP per capita

\begin{tabular}{|c|c|c|c|c|c|c|c|c|}
\hline & GDPPC & Rank & & GDPPC & Rank & & GDPPC & Rank \\
\hline Norway & 21,615 & 1 & Italy & 13,949 & 11 & Korea, Rep. & 3,615 & 21 \\
\hline Japan & 20,954 & 2 & Australia & 13,197 & 12 & Malaysia & 2,025 & 22 \\
\hline Denmark & 20,158 & 3 & Britain & 12,663 & 13 & Mexico & 1,775 & 23 \\
\hline Sweden & 19,559 & 4 & New Zealand & 11,050 & 14 & Chile & 1,742 & 24 \\
\hline United States & 18,973 & 5 & Hong Kong & 9,461 & 15 & Thailand & 1,050 & 25 \\
\hline Finland & 18,653 & 6 & Singapore & 8,656 & 16 & Philippines & 603 & 26 \\
\hline France & 16,608 & 7 & Spain & 7,956 & 17 & Indonesia & 468 & 27 \\
\hline Canada & 16,010 & 8 & Taiwan & 5,507 & 18 & Sri Lanka & 414 & 28 \\
\hline Netherlands & 15,129 & 9 & Greece & 4,829 & 19 & India & 346 & 29 \\
\hline Germany & 14,699 & 10 & Portugal & 4,438 & 20 & China & 272 & 30 \\
\hline
\end{tabular}

Note: $\quad$ GDPPC stands for GDP per capita in 1988 (constant prices, US $\$, 1987$ ). The ranking is calculated on the basis of GDPPC.

Source: Author's calculations.

The summary statistics for the dependent variables for each industry are given in Table 5 . Environmental stringency is calculated as an index on the basis of a country's level of development measured by GDP per capita in constant 1987 US dollars. For these 30 countries under study, the index number runs from 1 (strict) to 30 (tolerant). The lower the index number, the more stringent the country's environmental policy. 
No. 287 January 1999

\section{Empirical results}

Seemingly unrelated regression estimation (SURE) techniques are used to estimate equation (15) as a system. The estimation result and hypothesis tests are reported in Table 7. Standardised coefficients are reported in Table 9. For each equation, the dependent variable is the sectoral share in GDP in each country. The definitions of independent variables in this system equation are given in Table 8. Since the sectoral shares for each country will sum to one rather than one hundred, and the independent variables are all in logarithms, the interpretation of the coefficient carries the form of semi-elasticity. A parameter of 0.0013 indicates that a 10 per cent increase in the independent variable will raise the output share by 0.013 percentage points. Constant terms that absorbed the country fixed effect, scale effect, all goods prices effect and non-tradable goods technology effect are included in the regression but not reported in this table.

As shown in Table 7, the own-technology effects are all positive, as suggested by theory, and statistically significant at the 5 per cent level in most cases. The largest positive effects are in chemicals and paper and printing, with slope coefficients of 0.0146 and 0.0140 , respectively. This means that a 10 per cent technology improvement in the chemicals sector will lead to a 0.146 percentage point increase in its sectoral share of GDP and a 0.140 percentage point increase in the paper and printing sector. Technological improvement in the non-metal products sector has a small positive effect, but is only statistically significant at the 13.96 per cent level. The wood products sector shows a positive technological effect, but it is not statistically significant.

The cross-technology effects are, however, mixed as suggested by theory. In most cases, the cross-technology effects are small and statistically insignificant except the crosstechnology effects between the metal and non-metal sectors where they are negative and statistically significant. This result is similar to that in Harrigan's study (1997) using the OECD International Sectoral Data Base (ISDB), although he uses total factor productivity as an instrument of technology.

Turning now to the effects of the environmental factor on sectoral shares, it appears that environmental stringency has only a negligible effect and is shown to be not statistically significant in all sectors. This suggests that countries with less stringent environmental policy are not necessarily those with a higher sectoral share of ESGs. This finding confirms the time-series evidence, as suggested in Xu (1999b) and Xu and Song (1999). 
Pacific Economic Papers

Table 7 SURE estimates of the GDP share equations

\begin{tabular}{|c|c|c|c|c|c|}
\hline Variable & Wood Prod. & Paper \& Printing & Chemicals & Non-Metal & Metal \\
\hline LNT1 & $\begin{array}{c}0.0013 \\
(\mathbf{0 . 3 7 8 6})\end{array}$ & $\begin{array}{c}0.0007 \\
(0.2867)\end{array}$ & $\begin{array}{c}-0.0017 \\
(-0.6919)\end{array}$ & $\begin{array}{c}-0.0010 \\
(-0.4752)\end{array}$ & $\begin{array}{r}0.0019 \\
(1.1916)\end{array}$ \\
\hline LNT2 & $\begin{array}{c}0.0007 \\
(0.2867)\end{array}$ & $\begin{array}{c}0.0140 \\
\mathbf{( 4 . 1 3 9 1 )}\end{array}$ & $\begin{array}{c}-0.0041 \\
(-1.2265)\end{array}$ & $\begin{array}{c}0.0021 \\
(1.1167)\end{array}$ & $\begin{array}{r}0.0001 \\
(0.0600)\end{array}$ \\
\hline LNT3 & $\begin{array}{c}-0.0017 \\
(-0.6919)\end{array}$ & $\begin{array}{c}-0.0041 \\
(-1.2265)\end{array}$ & $\begin{array}{c}0.0146 \\
(\mathbf{2 . 6 0 7 0})\end{array}$ & $\begin{array}{c}-0.0035 \\
(-1.7179)\end{array}$ & $\begin{array}{r}-0.0009 \\
(-0.2885)\end{array}$ \\
\hline LNT4 & $\begin{array}{c}-0.0010 \\
(-0.4752)\end{array}$ & $\begin{array}{c}0.0021 \\
(1.1167)\end{array}$ & $\begin{array}{c}-0.0035 \\
(-1.7179)\end{array}$ & $\begin{array}{c}0.0042 \\
\mathbf{( 1 . 4 8 5 8 )}\end{array}$ & $\begin{array}{r}-0.0039 \\
(-3.2779)\end{array}$ \\
\hline LNT5 & $\begin{array}{c}0.0019 \\
(1.1916)\end{array}$ & $\begin{array}{c}0.0001 \\
(0.0600)\end{array}$ & $\begin{array}{c}-0.0009 \\
(-0.2885)\end{array}$ & $\begin{array}{c}-0.0039 \\
(-3.2779)\end{array}$ & $\begin{array}{r}0.0120 \\
\mathbf{( 3 . 1 7 9 5 )}\end{array}$ \\
\hline LNQ & $\begin{array}{c}0.0003 \\
(0.5098)\end{array}$ & $\begin{array}{c}-0.0015 \\
(-1.3582)\end{array}$ & $\begin{array}{c}0.0023 \\
(1.1105)\end{array}$ & $\begin{array}{c}0.0002 \\
(0.4058)\end{array}$ & $\begin{array}{r}0.0008 \\
(0.4644)\end{array}$ \\
\hline LNLD & $\begin{array}{c}0.0007 \\
(0.7061)\end{array}$ & $\begin{array}{c}0.0038 \\
\mathbf{( 2 . 1 3 6 8 )}\end{array}$ & $\begin{array}{c}-0.0112 \\
\mathbf{( - 3 . 2 1 6 0 )}\end{array}$ & $\begin{array}{c}-0.0030 \\
\mathbf{( - 3 . 2 0 9 8 )}\end{array}$ & $\begin{array}{r}-0.0025 \\
(-0.9479)\end{array}$ \\
\hline LNLB & $\begin{array}{c}-0.0016 \\
(-0.5823)\end{array}$ & $\begin{array}{c}0.0045 \\
(1.3165)\end{array}$ & $\begin{array}{c}0.0052 \\
(0.8368)\end{array}$ & $\begin{array}{c}0.0003 \\
(0.1159)\end{array}$ & $\begin{array}{r}0.0060 \\
(1.3184)\end{array}$ \\
\hline LNMI & $\begin{array}{c}0.0000 \\
(0.12826)\end{array}$ & $\begin{array}{c}-0.0011 \\
(-1.5911)\end{array}$ & $\begin{array}{c}0.0016 \\
(1.2273)\end{array}$ & $\begin{array}{c}0.0010 \\
(\mathbf{2 . 8 0 4 6 )}\end{array}$ & $\begin{array}{r}0.0009 \\
(0.9389)\end{array}$ \\
\hline LNOI & $\begin{array}{c}-0.0001 \\
(-0.6518)\end{array}$ & $\begin{array}{c}-0.0005 \\
\mathbf{( - 2 . 9 7 2 5 )}\end{array}$ & $\begin{array}{c}0.0003 \\
(0.8183)\end{array}$ & $\begin{array}{c}-0.0001 \\
(-0.5993)\end{array}$ & $\begin{array}{r}0.0000 \\
(-0.1702)\end{array}$ \\
\hline $\mathrm{LNCO}$ & $\begin{array}{c}0.0001 \\
(0.4227)\end{array}$ & $\begin{array}{c}0.0000 \\
(0.0563)\end{array}$ & $\begin{array}{c}0.0011 \\
(\mathbf{2 . 6 9 3 7 )}\end{array}$ & $\begin{array}{c}0.0002 \\
(\mathbf{2 . 2 2 6 4 )}\end{array}$ & $\begin{array}{r}0.0004 \\
(1.1547)\end{array}$ \\
\hline LNK & $\begin{array}{c}0.0005 \\
(0.1067)\end{array}$ & $\begin{array}{c}-0.0053 \\
(-0.7237)\end{array}$ & $\begin{array}{c}0.0007 \\
(0.0498)\end{array}$ & $\begin{array}{c}0.0013 \\
(0.3011)\end{array}$ & $\begin{array}{r}-0.0055 \\
(-0.5303)\end{array}$ \\
\hline Hypothesis Tests (p-valu & & & & & \\
\hline $\begin{array}{l}\text { Homogeneity } \\
\text { Significance tests }\end{array}$ & 0.860 & 0.130 & 0.912 & 0.582 & 0.217 \\
\hline A1: Technology & 0.0755 & 0.00002 & 0.0135 & 0.0072 & 0.00005 \\
\hline A2: Factor endowments & 0.6400 & 0.055 & 0.0019 & 0.0017 & 0.137 \\
\hline $\begin{array}{l}\text { A3: Technology \& Factor } \\
\text { endowments. }\end{array}$ & r $\quad 0.112$ & 0.0000 & 0.00005 & 0.00003 & 0.00006 \\
\hline
\end{tabular}

Notes: $\quad$ SURE estimation results are listed in each column, with t-statistics in parentheses. For a detailed definition of variables, see Table 8. Marginal significance levels of hypothesis tests are reported below the heading 'Hypothesis Tests' above. These are computed using the appropriate Wald statistic with Chi-square distribution. The hypothesis for the homogeneity test is that the sum of the factor endowment terms is zero. It is tested for each industry separately with $\chi^{2}(1)$. The hypothesis for A1 to A3 is that the indicated coefficients are all zero. The test statistics for A1 to A3 are $\chi^{2}(5), \chi^{2}(6), \chi^{2}(11)$, respectively.

Source: Author's calculations. 
Other resource endowment factors do have statistically significant effects on sectoral shares of GDP. The factor endowment effects underlying the new framework are essentially similar to that of Leamer (1984) and Song (1995) using the Heckscher-Ohlin-Vanek framework. Our findings include the following: a 10 per cent increase in the endowment of mineral resource is associated with 0.01 percentage increase in the non-metal sectoral share of GDP; countries with a relatively large endowment in coal are generally associated with high sectoral shares of chemicals and non-metals; countries with a larger endowment of oil are associated with a lower sectoral share of paper and printing; countries with a large amount of land (which includes forest land) endowment are associated with a higher share of paper and printing industries. A country's total labour force is not found to be significantly associated with high share of any one of the ESG sectors. The effects of capital endowment turn out to be insignificant in all cases. This might reflect the fact that capital is more mobile internationally than other natural resource endowment factors.

To understand the size of the effect of environmental stringency compared with the other factors, especially the technology factor, Table 9 shows the standardised coefficients of the SURE. The standardised coefficients are often known as 'beta' coefficients. They adjust the estimated coefficients by the ratio of the standard deviation of the independent variable to the standard deviation of the dependent variable. This makes it possible to compare the size of the effects of each independent variable directly. A standardised coefficient of 1.27 indicates that a one standard deviation increase in the independent variable will lead to an increase of the dependent variable by 1.27 standard deviation. More interestingly, a normalisation of standardised coefficients provides more intuitive insight as in Table 10, using a standardised coefficient of the technology variable in each column as the basis for carrying out this normalisation. Comparing the size of the effect of environmental stringency with that of technology, we can see that the average effect of environmental stringency on sectoral share is only 0.23 times the effect of the technology factor. 
Table 8 Definition of the variables

(1) LNT1 to LN T5: Log of the technology level for each industry starting from wood products in the first row in Table 7.6.

(2) LNQ: $\log$ of the environmental stringency index. Number 1 stands for the most stringent environmental policy while number 30 stands for the least stringent.

(3) LNLD: log of the land area.

(4) LNLB: log of the total labour force.

(5) LNOI: log of the oil factor endowment as defined in the text.

(6) LNMI: log of the mineral factor endowment as defined in the text.

(7) LNCO: log of the coal factor endowment as defined in the text.

(8) LNK: log of the capital stock as defined in the text.

\section{Table 9 Estimates of GDP share equation: standardised coefficients}

\begin{tabular}{|c|c|c|c|c|c|}
\hline Variable & Wood Prod. & Paper \& Printing & Chemicals & Non-Metal & Metal \\
\hline LNT1 & 0.3641 & 0.0651 & -0.0927 & -0.2496 & 0.1518 \\
\hline LNT2 & 0.1768 & 1.2666 & -0.2163 & 0.4785 & 0.0106 \\
\hline LNT3 & -0.4122 & -0.3541 & 0.7489 & -0.7747 & -0.0710 \\
\hline LNT4 & -0.2767 & 0.1953 & -0.1931 & 1.0036 & -0.3125 \\
\hline LNT5 & 0.4355 & 0.0112 & -0.0458 & -0.8090 & 0.8415 \\
\hline LNQ & 0.1581 & -0.2424 & 0.2246 & 0.0983 & 0.1065 \\
\hline LNLD & 0.3949 & 0.7400 & -1.2851 & -1.4779 & -0.4210 \\
\hline LNLB & -0.4858 & 0.4750 & 0.3210 & 0.0697 & 0.5424 \\
\hline LNMI & 0.0751 & -0.5597 & 0.4980 & 1.3391 & 0.4199 \\
\hline LNOI & -0.1491 & -0.4247 & 0.1336 & -0.1130 & -0.0312 \\
\hline LNCO & 0.1087 & 0.0092 & 0.5052 & 0.4759 & 0.2436 \\
\hline LNK & 0.0007 & -0.0034 & 0.0005 & 0.0012 & -0.0042 \\
\hline
\end{tabular}

Notes: The standardised coefficients are often known as 'beta' coefficients. They adjust the estimated coefficients by the ratio of the standard deviation of the independent variable to the standard deviation of the dependent variable. This makes it possible to compare the size of the effects of each independent variable directly.

Source: Author's calculations. 
No. 287 January 1999

Table 10 SURE estimates of GDP share equation: a normalisation of standardised coefficients

\begin{tabular}{lcccrr}
\hline Variable & Wood Prod. & Paper \& Printing & Chemicals & Non-Metal & Metal \\
\hline & & & & & \\
LNT1 & $\mathbf{1 . 0}$ & 0.1 & -0.1 & -0.2 & 0.2 \\
LNT2 & 0.5 & $\mathbf{1 . 0}$ & -0.3 & 0.5 & 0.0 \\
LNT3 & -1.1 & -0.3 & $\mathbf{1 . 0}$ & -0.8 & -0.1 \\
LNT4 & -0.8 & 0.2 & -0.3 & $\mathbf{1 . 0}$ & -0.4 \\
LNT5 & 1.2 & 0.0 & -0.1 & -0.8 & $\mathbf{1 . 0}$ \\
LNQ & $\mathbf{0 . 4}$ & $\mathbf{- 0 . 2}$ & $\mathbf{0 . 3}$ & $\mathbf{0 . 1}$ & $\mathbf{0 . 1}$ \\
LNLD & 1.1 & 0.6 & -1.7 & -1.5 & -0.5 \\
LNLB & -1.3 & 0.4 & 0.4 & 0.1 & 0.6 \\
LNMI & 0.2 & -0.4 & 0.7 & 1.3 & 0.5 \\
LNOI & -0.4 & -0.3 & 0.2 & -0.1 & 0.0 \\
LNCO & 0.3 & 0.0 & 0.7 & 0.5 & 0.3 \\
LNK & 0.0 & 0.0 & 0.0 & 0.0 & 0.0 \\
\hline
\end{tabular}

Note: $\quad$ Normalisation is carried out on the basis of Table 9.

Source: Author's calculations.

Hypothesis tests are shown in Table 7. The Wald statistics are computed for each hypothesis and the marginal significance levels are reported. The homogeneity restrictions are not rejected for all five cases. The technology factor and factor endowment are jointly significant (A3) at the 1 per cent level except in the case of the Wood sector where the significant level is 11.2 per cent. The technology factor and factor endowment are then tested separately (A1 and A2) and they are all significant at the 5 per cent level except that of the wood sector.

\section{Conclusion}

There are growing concerns in developing countries about the loss of international competitiveness and the impediments to economic development due to environmental regulation. Developed countries' concern about eco-dumping by developing countries with lax environmental policies has also become an important issue. This paper has attempted to investigate econometrically the effectiveness of 'eco-dumping', if any, on the international competitiveness of environmentally sensitive industries.

A generalised GNP function, which incorporated both technology change and increasing returns to scale, was set up and a flexible translog function form was used to approximate this 


\section{Pacific Economic Papers}

generalised GNP function. Seemingly unrelated regression estimation (SURE) techniques were used to estimate a system of sectoral share equations derived from the generalised GNP function. Environmental stringency is treated as a factor of production together with capital, land, labour, mineral, oil and coal endowments. The technology level is regarded as an important determinant of the sectoral share in production. The basic hypothesis is that the environmental factor is not a significant determinant of the international competitiveness of environmentally sensitive industries while technology is.

The econometric results suggest that the own-technology effects are all positive, as suggested by theory, and statistically significant at the 5 per cent level in most cases. However, the environmental stringency variable has only a negligible effect and is shown to be not statistically significant in all sectors. This suggests that countries with less stringent environmental policies do not necessarily have higher sectoral shares of ESGs. While trade is not explicitly addressed, the implication for trade is immediate: to the extent that countries have similar tastes, the inferences about the determinants of production patterns found here will translate into inferences about a country's trade patterns (Harrigan 1997). This finding confirms the time-series evidence as suggested in Xu (1999a) and Xu and Song (1999).

The policy implications are clear. On the one hand, these findings suggest that development strategies which rely on lax environmental regulations to achieve the economic goals of developing countries may not be appropriate since technological innovation may be a more relevant determinant of international trade competitiveness. There can be compromise between environmental standards and international competitiveness. Development strategies can take environmental standards into account.

On the other hand, the fear of eco-dumping from developing countries in the developed world seems ill-founded in light of these tests. The call for harmonisation of national environmental standards may not be justified, even from an empirical perspective.

\section{Notes}

1 When a firm sells products in another country at prices below average cost or below the price in the home country, it is called dumping. Dumping sometimes can be beneficial to importing countries if the reason for selling products at lower prices is that the foreign demand curve is more elastic and the firm just wants to price discriminate (Viner 1923). In practice, however, dumping is illegal in the United States and some other countries because it is regarded as a form of predatory pricing (Davis and McGuinness 1982; 
Ethier 1982) used by foreign firms to gain market share and market powers. The penalty is a high tariff or non-tariff barrier, or so-called anti-dumping duties.

2 See Xu (1999b) for a definition.

3 For an interesting analysis of global warming and developing countries, see Schelling (1992).

Woodland (1982) shows that the maximum GNP function G (p, v) is essentially the same as the minimum factor payment function $\mathrm{m}(\mathbf{p}, \mathbf{v})$. They are dual. The term GNP function is sometimes called the revenue function (Dixit and Norman 1980), or restricted profit function (Diewert 1974).

\section{References}

Anderson, Kym and Richard Blackhurst (1992) The Greening of World Trade Issues, Ann Arbor, University of Michigan Press.

Barrett, Scott (1994) 'Strategic environmental policy and international trade', Journal of Public Economics, 54(3): 325-38.

Barro, Robert J. and Xavier Sala-i-Martin (1995) Economic growth, McGraw-Hill.

Bhagwati, Jagdish and Robert E. Hudec (1996) Fair Trade And Harmonization: Prerequisites for Free Trade?, Cambridge and London, MIT Press.

Brander, James A. and M. Scott Taylor (1997) 'International trade between consumer and conservationist countries', Resource and Energy Economics, 19: 267-97.

Chichilnisky, Graciela (1994) 'North-South trade and the global environment', American Economic Review, 84(4): 851-74.

Christensen, Laurits R., Dale W. Jorgenson and Lawrence J. Lau (1971) 'Conjugate duality and the transcendental logarithmic production function (abstract)', Econometrica, 39(4): $255-56$.

Coase, R. H. (1960) 'The problem of social cost', Journal of Law and Economics, III (October): $1-44$.

Dasgupta, S., A. Mody, A Roy and D. Wheeler (1995) 'Environmental regulation and development: a cross-country empirical analysis', World Bank Policy Research Working Paper No. 1448: 1-24.

Davies, Stephen W. and Anthony J. McGuinness (1982) 'Dumping at less than marginal cost', Journal of International Economics, 12(1/2): 169-82.

Diewert, W. Erwin (1974) 'Functional forms for revenue and factor requirements functions', International Economic Review: 15(1): 119-30.

Dixit, Avinash and Victor Norman (1980) The Theory of International Trade Cambridge, Cambridge University Press.

Drysdale, Peter (1988), International Economic Pluralism: Economic Policy in East Asia and the Pacific, Sydney, Allen \& Unwin.

Drysdale, Peter and Ross Garnaut (1982) 'Trade intensities and the analysis of bilateral trade flows in a many-country world', Hitotsubashi Journal of Economics, 22(2): 62-84. 
Dua, Andre and Daniel C. Esty (1997) Sustaining the Asia Pacific Miracle: Environmental Protection and Economic Integration, Washington DC, Institute for International Economics.

Esty, Daniel C. (1994) Greening the GATT: Trade, Environment, and the Future, Washington DC, Institute for International Economics.

Ethier, Wilfred J. (1982) 'Dumping', Journal of Political Economy, 90(3): 487-506.

Harrigan, James (1997) 'Technology, factor supplies, and international specialization: estimating the neoclassical model', American Economic Review, 87(4): 475-94.

Kohli, Ulrich R. (1978) 'A gross national product function and the derived demand for imports and supply of exports', Canadian Journal of Economics, 11(2): 167-82.

Kohli, Ulrich R. (1991) Technology, Duality, and Foreign Trade: the GNP Function Approach to Modeling Imports and Exports. Ann Arbor, University of Michigan Press.

Kohli, Ulrich R. (1993) 'A symmetric normalized quadratic GNP Function and the U.S. demand for imports and supply of exports', International Economic Review, 34(1): $243-55$.

Markusen, James R. (1997) 'Costly pollution abatement, competitiveness, and plant location decisions', Resource and Energy Economics, 19: 299-320.

OECD (1995) 'Report on trade and environment to the OECD council at Ministerial Level', Organisation for Economic Cooperation and Development.

Porter, Michael E. and Claas van der Linde (1995) 'Toward a new conception of the environment-competitiveness relationship', Journal of Economic Perspectives, 9(4): 97-118.

Rauscher, Michael (1994) 'On ecological dumping', Oxford Economic Papers, 46(5): 822-40.

Samuelson, P.A. (1953) 'Prices of factors and goods in general equilibrium', Review of Economic Studies, 21(1): 1-20.

Schelling, Thomas C. (1992) 'Some economics of global warming', American Economic Review, 82(1): 1-14.

Song, Ligang (1996) Changing Global Comparative Advantage: Evidence from Asia and the Pacific, Melbourne, Addison Wesley Longman.

Tobey, James A. (1990) 'The effects of domestic environmental policies on patterns of world trade: an empirical test', Kyklos, 43(2): 191-209.

UNIDO (1992) Handbook of Industrial Statistics, United Nations Industrial Development Organization, New York, United Nations.

Viner, J. (1923) Dumping: A Problem in International Trade, Chicago, University of Chicago Press.

Vousden, Neil (1990) 'The Economics of Trade Protection', Cambridge, Cambridge University Press.

Walter, Ingo and Judith Ugelow (1979) 'Environmental policies in developing countries', Ambio, 8(2, 3): 102-109.

Woodland, A.D. (1982) International Trade and Resource Allocation Amsterdam: NorthHolland.

$\mathrm{Xu}$, Xinpeng (1999a) 'International trade and environmental regulation: a dynamic perspective', Ph.D. dissertation, Australian National University. 
$\mathrm{Xu}$, Xinpeng (1999b) 'Do stringent environmental regulations reduce the international competitiveness of environmentally sensitive industries? a global perspective', World Development, forthcoming.

$\mathrm{Xu}$, Xinpeng and Ligang Song (1999) 'Regional cooperation and the environment: do "dirty" industries migrate', paper presented at Kobe University and Australian National University joint seminar, Australia, Japan and APEC, Kobe, Japan, January 19. 


\section{Previous Pacific Economic Papers}

286 APEC and the new transatlantic marketplace proposal: open regionalism going global?

Andrew Elek, December 1998

285 Realism and postwar US trade policy

John Kunkel, November 1998

284 Attracting FDI: Australian government investment promotion in Japan, 1983-96 Jamie Anderson, October 1998

283 The Multi-function polis 1987-97: an international failure or innovative local project?

Paul Parker, September 1998

282 Organisation, motivations and case studies of Japanese direct investment in real estate $1985-94$

Roger Farrell, August 1998

281 Japan's approach to Asia Pacific economic cooperation

Peter Drysdale, July 1998

280 The politics of telecommunications reform in Japan

Hidetaka Yoshimatsu, June 1998

279 Sustainability of growth in the Korean manufacturing sector Chang-Soo Lee, May 1998

278 Export performance of environmentally sensitive goods: a global perspective Xinpeng Xu, April 1998

277 Modelling manufactured exports: evidence for Asian newly industrialising economies

Francis In, Pasquale Sgro and Jai-Hyung Yoon, March 1998

276 Laos in the ASEAN free trade area: trade, revenue and investment implications Jayant Menon, February 1998

275 Globalisation

Heinz Arndt, January 1998

274 The WTO and APEC: What role for China?

Stuart Harris, December 1997

273 The APEC air transport schedule

Christopher Findlay, November 1997

272 Japanese foreign direct investment in real estate 1985-1994

Roger Farrell, October 1997 
271 China and East Asia trade policy volume 4: Trade reform and liberalisation in China

Yang Shengming, Zhong Chuanshui, Yongzheng Yang, Feng Lei, Yiping Huang, and Pei Changhong, September 1997

270 The politics of economic reform in Japan

T.J. Pempel, Tony Warren, Aurelia George Mulgan, Hayden Lesbirel, Purnendra Jain and Keiko Tabusa, August 1997

269 Diplomatic strategies: the Pacific Islands and Japan Sandra Tarte, July 1997

268 Interest parity conditions as indicators of financial integration in East Asia Gordon de Brouwer, June 1997

267 Consensus in conflict: competing conceptual structures and the changing nature of Japanese politics in the postwar era Lindy Edwards, May 1997

266 The role of foreign pressure (gaiatsu) in Japan's agricultural trade liberalisation Aurelia George Mulgan, April 1997

265 Transformation in the political economy of China's economic relations with Japan in the era of reform Dong Dong Zhang, March 1997

264 Economic relations across the Strait: interdependence or dependence? Heather Smith and Stuart Harris, February 1997

263 Has Japan been 'opening up'?: empirical analytics of trade patterns Jayant Menon, January 1997

262 Postwar private consumption patterns of Japanese households: the role of consumer durables Atsushi Maki, December 1996

261 East Asia and Eastern Europe trade linkages and issues Jocelyn Horne, November 1996

260 National choice Wang Gungwu, October 1996

259 Australia's export performance in East Asia Peter Drysdale and Weiguo Lu, September 1996

258 Public infrastructure and regional economic development: evidence from China Weiguo Lu, August 1996

257 Regional variations in diets in Japan Paul Riethmuller and Ruth Stroppiana, July 1996 


\section{Pacific Economic Papers}

256 Japanese FDI in Australia in the 1990s: manufacturing, financial services and tourism

Stephen Nicholas, David Merrett, Greg Whitwell, William Purcell with Sue Kimberley, June 1996

255 From Osaka to Subic: APEC's challenges for 1996 Andrew Elek, May 1996

254 NAFTA, the Americas, AFTA and CER: reinforcement or competition for APEC? Richard H. Snape, April 1996

253 Changes in East Asian food consumption: some implications for Australian irrigated agriculture

Philip Taylor and Christopher Findlay, March 1996

252 Behaviour of Pacific energy markets: the case of the coking coal trade with Japan Richard J. Koerner, February 1996

251 Intra-industry trade and the ASEAN free trade area Jayant Menon, January 1996

250 China and East Asia trade policy, volume 3:

China and the world trade system

Various authors, December 1995 (special volume)

\section{Annual subscription rate for twelve issues:}

Individuals AS60.00

Institutions $\mathrm{A} \$ 100.00$

\section{Cost for single issues:}

$\mathrm{A} \$ 15.00$

$\mathrm{A} \$ 10.00$ (Students)

All prices include postage

Available from: Publications Department

Australia-Japan Research Centre

Asia Pacific School of Economics and Management

The Australian National University

Canberra ACT 0200, Australia

Facsimile: (612) 62490767

Telephone:(61 2) 62493780

Email:ajrcgen@ajrc.anu.edu.au

URL:http://ajrcnet.anu.edu.au/ 